\title{
NOTARIS DALAM STATUS TERPIDANA YANG MASIH MENJALANKAN JABATANNYA
}

\author{
Franky Roberto Gomies \\ Fakultas Hukum Universitas Surabaya, email : wpfranky26@gmail.com
}

\begin{abstract}
The purpose of this study is to determine the authority of a Notary Public in the period of parole in carrying out his position as a public official making an authentic deed and knowing the legal position of an authentic deed made by a Notary during the parole who performs the duties of a Notary Public. This type of research is normative juridical by using the statutory approach, conceptual approach and case approach. From the results of the study note: First, the position of notary public, besides being a public official as well as a public official, so a notary must always maintain his honor and dignity and have a good personality. When a notary public commits a criminal offense, the Notary Position Act will also impose administrative sanctions. Of the cases examined in this study, a notary was sentenced to a criminal sentence for drug abuse, returning to his position as a notary public to serve the public while undergoing a period of parole. This is due to the negligence of the notary Supervisory Council that has been formed in stages starting from the Regional Supervisory Council, Regional Supervisory Council and Central Supervisory Council, which does not carry out its duties, functions and obligations properly. The two acts of notary that have legally lost their authority but re-practiced and served the community are acts that are carried out without authority so that the deed they make does not have power as an authentic deed.
\end{abstract}

Keywords: authority; administrative sanctions; authentic deed.

\section{Pendahuluan}

Notaris merupakan suatu jabatan terhormat yang diberikan oleh Negara melalui undang-undang kepada orang yang mempunyai keahlian. Keberadaan lembaga notaris dikehendaki oleh aturan hukum dengan tujuan untuk memberikan kepastian dan perlindungan hukum bagi masyarakat yang membutuhkan alat bukti tertulis yang bersifat otentik. Menurut Sjaifurrachman dan Habib Adjie (2011, hlm 55), kewenangan utama yang dimiliki oleh Pejabat Umum adalah membuat akta otentik. Selanjutnya Soegondo Notodisoejo mengatakan bahwa:

"Pejabat umum adalah seorang yang diangkat dan diberhentikan oleh Pemerintah dan diberi wewenang dan kewajiban untuk melayani publik dalam hal-hal tertentu karena ia ikut serta melaksanakan suatu kekuasaan yang bersumber pada kewibawaan (gezag) dari Pemerintah. Dalam jabatannya tersimpul suatu sifat dan ciri khas yang membedakannya dari jabatan-jabatan lainnya dalam masyarakat".

Di Indonesia keberadaan notaris telah ada sejak zaman kolonial Belanda yang kemudian dinasionalisasi dengan diundangkannya Undang-Undang Nomor 30 Tahun 2004 yang kemudian diubah dengan Undang-Undang Nomor 2 Tahun 2014 tentang Jabatan Notaris (selanjutnya disebut UUJN).

Kedudukan Notaris sebagai pejabat umum dituntut profesional dalam menjalankan jabatannya yaitu membuat keterangan atau membuat akta sebagai alat bukti tertulis yang mempunyai kekuatan pembuktian yang sempurna. Notaris merupakan jabatan yang memiliki harkat dan martabat yang sangat tinggi dan terhormat. Dalam menjalankan tugas dan fungsinya melayani masyarakat dalam bidang keperdataan maka Notaris harus senantiasa menjaga martabatnya karena jabatan yang diembannya adalah jabatan kepercayaan yang diberikan oleh pemerintah berdasarkan undang-undang. Namun pada praktiknya masih saja ada Notaris yang melakukan kesalahan atau melakukan perbuatan yang melanggar aturan hukum baik dalam menjalankan jabatannya maupun di luar jabatannya yang pada akhirnya dijatuhi sanksi oleh aparat penegak hukum.

Sejak kehadiran institusi Notaris di Indonesia, lembaga yang bertugas melakukan pengawasan terhadap Notaris adalah lembaga peradilan dan pemerintah, namun setelah berlakunya UUJN, lembaga peradilan tidak lagi berwenang melakukan pengawasan. Pengawasan terhadap Notaris dilakukan dengan maksud agar setiap Notaris dalam 
menjalankan tugas jabatannya harus memenuhi semua prosedur dan persyaratan yang berkaitan dengan pelaksanaan tugas jabatan Notaris sehingga dapat memberikan jaminan kepastian dan perlindungan hukum bagi masyarakat yang menggunanakan jasa Notaris.

Lembaga yang berwenang melakukan pengawasan terhadap Notaris menurut Pasal 67 ayat (1) UUJN yaitu Menteri. Menteri yang dimaksud dalam hal ini adalah Menteri Hukum dan HAM. Dalam melakukan pengawasan terhadap Notaris, Menteri membentuk Majelis Pengawas Notaris atau disebut Majelis Pengawas. Majelis Pengawas adalah suatu badan yang mempunyai kewenangan dan kewajiban untuk melaksanakan pembinaan dan pengawasan terhadap Notaris. Berdasarkan definisi tersebut dapat disimpulkan bahwa kewenangan utama Pengawas Notaris adalah melakukan pembinaan dan pengawasan. Majelis Pengawas terdiri atas Majelis Pengawas Daerah; Majelis Pengawas Wilayah; dan Majelis Pengawas Pusat. Seringkali terjadi bahwa Notaris dengan sengaja melakukan perbuatan yang merendahkan kehormatan dan martabat Jabatan Notaris. Yang dimaksud dengan perbuatan yang merendahkan kehormatan dan martabat menurut penjelasan Pasal 12 huruf c UUJN yaitu berjudi, mabuk, menyalah gunakan narkoba, dan berzina. Sanksi terhadap Notaris yang melakukan perbuatan yang merendahkan kehormatan dan martabat Jabatan Notaris adalah pemberhentian dengan tidak hormat.

Di Kota Tual, yang berada di dalam wilayah Kabupaten Maluku Tenggara, pengawasan terhadap notaris disana dilakukan oleh Majelis Pengawas Daerah gabungan dikarenakan minimnya jumlah Notaris di kota tersebut. Minimnya pengawasan Notaris di Kota Tual mengakibatkan banyaknya jumlah pelanggaran-pelanggaran yang dilakukan oleh para Notaris. Notaris yang melakukan pelanggaran pun dapat terlepas dari sanksi-sanksi yang seharusnya diberikan oleh Majelis Pengawas Daerah. Seperti dalam sebuah kasus yang terjadi, dimana seorang Notaris ditangkap dan dijatuhi hukuman 2 (dua) tahun penjara karena menyalahgunakan narkoba, berdasarkan putusan Pengadilan Negeri Tual Nomor : 35/Pid.Sus/2013/PN.TL. Namun, meskipun telah menerima sanksi pidana, Notaris tersebut sama sekali tidak menerima sanksi pemberhentian sementara atau sanksi lainnya yang lebih tegas oleh Majelis Pengawas Daerah. Hal ini tentunya bertentangan dengan Pasal 9 ayat (1) huruf e UUJN yang menegaskan bahwa seorang Notaris diberhentikan sementara dari jabatannya apabila sedang menjalani masa penahanan.

Selanjutnya pada saat Notaris tersebut mendapatkan hak pembebasan bersyarat. Ia kembali menjalankan jabatannya sebagai Notaris dan membuat akta otentik. Hal ini dikarenakan tidak adanya sanksi berupa pemberhentian sementara oleh Majelis Pengawas sehingga Notaris tersebut dengan sengaja menjalankan jabatannya walaupun masih terikat status terpidana. Hal ini mengakibatkan kewenangan Notaris tersebut menjadi tidak jelas dan akta yang dibuatnya juga menjadi tidak jelas kedudukan hukumnya sehingga dapat merugikan masyarakat yang menggunakan jasa Notaris tersebut.

Berdasarkan uraian di atas, permasalahan yang akan dikaji adalah : 1) Bagaimana kewenangan Notaris dalam masa pembebasan bersyarat dalam menjalankan jabatan sebagai pejabat umum membuat akta otentik? 2) Bagaimana kedudukan hukum terhadap akta otentik yang dibuat oleh Notaris dalam masa pembebasan bersyarat yang menjalankan tugas jabatan Notaris?

\section{Pembahasan}

\subsection{Kewenangan Menjalankan Jabatan Bagi Notaris Yang Sedang Dalam Masa Pembebasan} Bersyarat

Notaris sebagai Pejabat Umum diciptakan dengan tujuan untuk membantu dan melayani masyarakat yang memerlukan alat bukti mengenai peristiwa atau perbuatan hukum yang terjadi/dilakukan. Oleh karenanya notaris diberikan kewenangan dalam menjalankan tugas jabatannya untuk melayani masyarakat. Kewenangan notaris harus diatur secara tegas dan jelas dalam peraturan perundang-undangan mengenai jabatan notaris, sehingga apabila seorang notaris melakukan tindakan diluar kewenangannya dapat disebut sebagai perbuatan melanggar hukum.

Secara teoritis kewenangan yang bersumber dari peraturan perundang-undangan diperoleh melalui tiga cara, yakni (Philipus M. Hadjon, 2010, h.20) :

a. Atribusi

Atribusi dalam bahasa latin dari kata ad tribuere artinya memberikan kepada. Konsep teknis hukum tata negara dan hukum administrasi mengartikan wewenang atribusi adalah wewenang yang diberikan atau ditetapkan untuk jabatan tertentu. Dengan demikian wewenang atribusi merupakan wewenang yang melekat pada suatu jabatan. 
b. Delegasi

Delegasi berasal dari bahasa latin delegare yang artinya melimpahkan. Dengan demikian konsep wewenang delegasi adalah wewenang pelimpahan.

c. Mandat

Mandat berasal dari bahasa latin mandare yang artinya memerintahkan. Dengan demikian konsep mandat mengandung makna penugasan.

Dari ketiga sumber kewenangan itu, kewenangan notaris sebagai pejabat umum yang melayani masyarakat dalam pembuatan alat bukti, bersumber dari atribusi yaitu pemberian wewenang berdasarkan peraturan perundang-undangan yang melekat pada suatu jabatan.

Setiap wewenang selalu dibatasi oleh isi/materi (materiae), wilayah/daerah (locus), dan waktu (tempus). Demikian pula dengan wewenang notaris dibatasi juga oleh :

a. Isi (materiae)

Isi (materiae) wewenang yang diberikan kepada notaris telah diatur dalam Pasal 15 ayat (1) UUJN, yang pada intinya kewenangan umum notaris adalah :

1) membuat akta otentik mengenai semua perbuatan atau perjanjian atau ketetapan yang disyaratkan/diharuskan oleh peraturan perundang-undangan. Perbuatan atau perjanjian yang diharuskan oleh peraturan perundang-undangan itu misal, akta pendirian perseroan terbatas, jaminan fidusia yang oleh peraturan harus dibuat dalam bentuk akta otentik (baca: akta notaris).

2) karena dikehendaki oleh para pihak walau tidak diharuskan oleh peraturan perundang-undangan. Misal, perjanjian sewa menyewa walau tidak diharuskan oleh peraturan perundang-undangan, di dalam prakteknya banyak dibuat dengan akta notaris agar memiliki kekuatan pembuktian yang sempurna.

3) dari pembuatan akta otentik itu, notaris berwenang menjamin kepastian tanggal, menyimpan akta, memberikan grosse, salinan dan kutipan Akta.

Adapun pembatasan isi (materiae) wewenang notaris adalah sebagaimana dimaksud dalam Pasal 15 ayat (1) UUJN pada frasa kata : "...semuanya itu sepanjang pembuatan Akta itu tidak juga ditugaskan atau dikecualikan kepada pejabat lain atau orang lain yang ditetapkan oleh undang-undang." Yang memberikan pengertian, bahwa jika suatu perbuatan atau perjanjian atau ketetapan yang oleh undang-undang telah ditugaskan kepada pejabat lain maka notaris tidak berwenang untuk membuatkan akta otentik mengenai perbuatan atau perjanjian atau ketetapan itu.

b. Wilayah / Daerah (locus)

Wewenang notaris juga dibatasi oleh wilayah / daerah (locus). Pembatasan wewenang notaris ini berkaitan dengan unsur-unsur akta otentik yang diatur dalam Pasal 1868 KUH Perdata, yaitu unsur ketiga mengenai tempat, dimana akta itu dibuat. Di dalam ketentuan Pasal 18 UUJN, yang menyebutkan :

(1) Notaris mempunyai tempat kedudukan di daerah kabupaten atau kota.

(2) Notaris mempunyai wilayah jabatan meliputi seluruh wilayah provinsi dari tempat kedudukannya.

Selanjutnya Pasal 17 ayat (1) huruf a UUJN menyatakan : "Notaris dilarang menjalankan jabatan di luar wilayah jabatannya." Sedangkan ketentuan Pasal 19 ayat (3) yang menyatakan : "Notaris tidak berwenang secara berturut-turut dengan tetap menjalankan jabatan di luar tempat kedudukannya."

Ketentuan diatas mengandung pengertian bahwa notaris berwenang membuat akta otentik hanya di dalam wilayah tertentu saja yaitu di tempat kedudukan notaris (yang berada didalam wilayah kota/kabupaten) dan "sesekali" berwenang membuat akta di luar tempat kedudukannya selama masih dalam wilayah jabatan.

Notaris harus berwenang sepanjang mengenai tempat, dimana akta itu dibuat. Pasal 18 ayat (1) Undang-Undang Jabatan Notaris menentukan bahwa Notaris harus berkedudukan di daerah kabupaten atau kota. Setiap Notaris sesuai dengan keinginannya mempunyai tempat kedudukan dan berkantor di daerah di kabupaten atau kota (Pasal 19 ayat (1) Undang-Undang Jabatan Notaris). Notaris mempunyai wilayah jabatan meliputi seluruh wilayah propinsi dari tempat kedudukannya (Pasal 19 ayat (2) Undang-Undang Jabatan Notaris). Pengertian pasal-pasal tersebut bahwa Notaris dalam menjalankan tugas jabatannya tidak hanya harus berada di tempat kedudukannya, karena Notaris mempunyai wilayah jabatan seluruh propinsi. Hal ini dapat dijalankan dengan ketentuan: 
a) Notaris ketika menjalankan tugas jabatannya (membuat akta) di luar tempat kedudukannya, maka Notaris tersebut harus berada ditempat akta akan dibuat.

b) Pada akhir akta harus disebutkan tempat (kota atau kabupaten) pembuatan dan penyelesaian akta.

c) Menjalankan tugas dan jabatan di luar tempat kedudukan Notaris dalam wilayah jabatan satu propinsi tidak merupakan suatu keteraturan atau tidak terus menerus (vide Pasal 19 ayat (2) UUJN).

Ketentuan tersebut dalam praktek memberikan peluang kepada Notaris untuk merambah dan melintasi batas dari tempat kedudukan dalam pembuatan akta. Meskipun bukan suatu hal yang dilarang untuk dilakukan karena yang dilarang menjalankan tugas dan jabatannya di luar wilayah jabatannya atau di luar propinsi (Pasal 17 huruf a Undang-Undang Jabatan Notaris), tapi untuk saling menghormati sesama Notaris di kabupaten atau kota lain lebih baik hak seperti itu tidak dilakukan.

c. Waktu (tempus)

Notaris berwenang membuat akta otentik sejak diangkat hingga berhenti/diberhentikan. Dengan pengecualian dalam kurun waktu itu terdapat hal-hal yang menjadikan notaris menjadi tidak berwenang walaupun belum berhenti/diberhentikan, yaitu dalam hal :

1) cuti

2) diberhentikan sementara.

Notaris dalam menjalankan tugas jabatannya harus dalam keadaan aktif, artinya tidak dalam keadaan cuti atau diberhentikan sementara waktu. Notaris yang sedang cuti, sakit atau berhalangan sementara waktu. Notaris yang sedang cuti, sakit atau berhalangan sementara untuk menjalankan tugas jabatannya. Agar tidak terjadi kekosongan, maka Notaris yang bersangkutan dapat menunjuk Notaris Pengganti (Pasal 1 angka 3 Undang-Undang Jabatan Notaris).

Ketiga aspek pembatasan wewenang notaris tersebut, maka pelanggaran terhadap hal tersebut akan menimbulkan cacat wewenang atau dalam artian bahwa di luar-luar batas-batas itu merupakan tindakan tanpa wewenang (onbevoegdheid).

3. Ruang Lingkup Kewenangan Notaris Menurut UUJN

Notaris mempunyai kewenangan yang ditentukan dalam Pasal 15 UUJN. Pasal 15 UUJN menentukan kewenangan-kewenangan yang dapat dilakukan oleh Notaris adalah sebagai berikut :

1) Notaris berwenang membuat akta autentik mengenai semua perbuatan, perjanjian, dan penetapan yang diharuskan oleh peraturan perunfang-undangan dan/atau yang dikehendaki oleh yang berkepentingan untuk dinyatakan dalam Akta autentik, menjamin kepastian tanggal pembuatan Akta, menyimpan Akta, memberikan grosse, salinan kutipan Akta, semuanya itu sepanjang pembuatan Akta itu tidak juga ditugaskan atau dikecualikan kepada pejabat lain atau orang lain yang ditetapkan oleh undangundang.

2) Selain kewenangan sebagaimana dimaksud pada ayat (1), Notaris berwenang pula:

a. Mengesahkan tanda tangan dan menetapkan kepastian tanggal surat di bawah tangan dengan mendaftar dalam buku khusus;

b. Membukukan surat di bawah tangan dengan mendaftar dalam buku khusus;

c. Membuat kopi dari asli surat dibawah tangan berupa salinan yang memuat uraian sebagaimana ditulis dan digambarkan dalam surat yang bersangkutan;

d. Melakukan pengesahan kecocokan fotokopi dengan surat aslinya;

e. Melakukan penyuluhan hukum sehubungan dengan pembuatan Akta;

f. Membuat Akta yang berkaitan dengan pertanahan; atau

g. Membuat Akta risalah lelang.

3) Selain kewenangan sebagaimana dimaksud pada ayat (1) dan ayat (2), Notaris mempunyai kewenangan lain yang diatur dalam perundang-undangan.

Notaris sebagai pejabat umum, dalam menjalankan jabatannya memiliki kewajiban untuk selalu berpedoman pada UUJN dan peraturan perundang-undangan lainnya.

4. Sanksi Administratif Terhadap Notaris Yang Melakukan Tindak Pidana 
Notaris memperoleh kewenangan berdasarkan undang-undang untuk melayani masyarakat yang memerlukan alat bukti. Dengan demikian dapat diartikan Notaris merupakan pejabat publik. Oleh karenanya guna menjaga kehormatan dan martabatnya, Notaris dalam menjalankan kewenangannya sebagai pejabat publik harus selalu tunduk pada undang-undang yang berlaku serta mempunyai kepribadian yang baik. Selain berpedoman pada undang-undang, notaris dapat dikatakan mempunyai perilaku yang baik jika berlandaskan kode etik dan asas-asas hukum.

Notaris merupakan profesi/jabatan yang dipercaya masyarakat, ketika seorang notaris melakukan perbuatan yang melanggar ketentuan dalam undang-undang dan yang berakibat merendahkan kehormatan dan martabat hingga kemudian dijatuhi sanksi pidana, maka disamping sanksi penal yang dijatuhkan pengadilan kepada notaris tersebut, UUJN juga akan memberikan sanksi administratif.

Adapun sanksi yang dikenakan kepada oleh Notaris yang terdapat di dalam UUJN adalah sebagai berikut:

a. Peringatan tertulis

Sanksi tertulis ini merupakan peringatan atau teguran awal agar seseorang tidak melakukan atau takut untuk melakukan pelanggaran kembali.

b. Pemberhentian sementara

Sanksi pemberhentian sementara atau skorsing ini agar notaris untuk tidak melaksanakan jabatannya sementara waktu. Hal-hal yang dapat menyebabkan notaris diberikan sanksi pemberhentian sementara karena :

a. dalam proses pailit atau penundaan kewajiban pembayaran utang;

b. berada di bawah pengampuan;

c. melakukan perbuatan tercela;

d. melakukan pelanggaran terhadap kewajiban dan larangan jabatan serta kode etik Notaris; atau

e. sedang menjalani masa penahanan.

c. Pemberhentian tidak hormat

Pemberhentian tidak hormat merupakan pemberhentian notaris dari jabatannya sehingga seseorang tidak dapat menjadi notaris kembali. Hal-hal yang menyebabkan Notaris diberhentiaan tidak hormat (vide Pasal 12 UUJN) adalah :

a. dinyatakan pailit berdasarkan putusan pengadilan yang telah memperoleh kekuatan hukum tetap;

b. berada di bawah pengampuan secara terus-menerus lebih dari 3 (tiga) tahun;

c. melakukan perbuatan yang merendahkan kehormatan dan martabat jabatan Notaris; atau

d. melakukan pelanggaran berat terhadap kewajiban dan larangan jabatan.

Di dalam penjelasan Pasal 12 huruf c dan d dinyatakan :

c. Yang dimaksud dengan "perbuatan yang merendahkan kehormatan dan martabat" misalnya berjudi, mabuk, menyalah gunakan narkoba, dan berzina.

d. Yang dimaksud dengan "pelanggaran berat" adalah tidak memenuhi kewajiban dan melanggar larangan jabatan Notaris.

Sedangkan Pasal 13 menyebutkan :

"Notaris diberhentikan dengan tidak hormat oleh Menteri karena dijatuhi pidana penjara berdasarkan putusan pengadilan yang telah memperoleh kekuatan hukum tetap karena melakukan tindak pidana yang diancam dengan pidana penjara 5 (lima) tahun atau lebih."

Ketentuan tersebut mengandung pengertian bahwa apabila seorang notaris telah dinyatakan bersalah dan dihukum pidana berdasarkan putusan pengadilan yang telah inkracht, maka tanpa perlu diusulkan oleh Majelis Pengawas, Menteri dapat langsung memberhentikan dengan tidak hormat terhadap notaris yang telah di vonis pidana, dengan ancaman paling lama 5 (lima) tahun atau lebih, walaupun vonisnya dibawah 5 (lima).

5. Lembaga Pengawas Notaris

UUJN telah mengamanatkan pengawasan terhadap notaris dilakukan oleh Menteri (vide Pasal 67 ayat (1) UUJN) dalam hal ini adalah Menteri Hukum dan Hak Asasi Manusia (Menkumham). 
Untuk mengawasi pelaksanaan tugas jabatan notaris, Kemenkumham membentuk Majelis Pengawas Notaris (MPN) yang berupa badan yang mempunyai kewenangan dan kewajiban untuk melaksanakan pembinaan dan pengawasan terhadap Notaris (vide Pasal 1 angka 6 UUJN). MPN berjumlah 9 (sembilan) orang yang terdiri dari atas unsur pemerintah 3 (tiga) orang, unsur organisasi notaris 3 (tiga) orang dan unsur ahli/akademisi 3 (tiga) orang. MPN memiliki jenjang yaitu Majelis Pengawas Daerah (MPD) yang dibentuk di Kabupaten/Kota, Majelis Pengawas Wilayah yang dibentuk dan berkedudukan di ibukota provinsi, serta Majelis Pengawas Pusat yang dibentuk dan berkedudukan di ibukota negara. Masing-masing jenjang Majelis pengawas diberikan kewenangan yang berbeda.

a. Kewenangan Majelis Pengawas Daerah (MPD)

Kewenangan MPD diatur dalam Pasal 70 UUJN, antara lain :

a) menyelenggarakan sidang untuk memeriksa adanya dugaan pelanggaran Kode Etik Notaris atau pelanggaran pelaksanaan jabatan Notaris;

b) melakukan pemeriksaan terhadap Protokol Notaris secara berkala 1 (satu) kali dalam 1 (satu) tahun atau setiap waktu yang dianggap perlu;

c) memberikan izin cuti untuk waktu sampai dengan 6 (enam) bulan;

d) menetapkan Notaris Pengganti dengan memperhatikan usul Notaris yang bersangkutan;

e) menerima laporan dari masyarakat mengenai adanya dugaan pelanggaran Kode Etik Notaris atau pelanggaran ketentuan dalam Undang-Undang ini; dan

f) membuat dan menyampaikan laporan kepada Majelis Pengawas Wilayah.

b. Kewenangan Majelis Pengawas Wilayah (MPW)

Kewenangan MPW diatur dalam Pasal 73 dan Pasal 74 UUJN, antara lain ::

a) menyelenggarakan sidang untuk memeriksa dan mengambil keputusan atas laporan masyarakat yang disampaikan melalui MPW;

b) memanggil Notaris terlapor untuk dilakukan pemeriksaan atas laporan sebagaimana dimaksud pada huruf a;

c) memeriksa dan memutus atas keputusan MPD yang menolak cuti yang diajukan oleh Notaris pelapor;

d) memberikan sanksi berupa teguran lisan atau tertulis;

e) mengusulkan pemberian sanksi terhadap Notaris kepada MPP berupa:

1) pemberhentian sementara 3 (tiga) bulan sampai dengan 6 (enam) bulan; atau

2) pemberhentian dengan tidak hormat.

f) membuat berita acara atas setiap keputusan penjatuhan sanksi;

Keputusan MPW bersifat final. Notaris berhak untuk membela diri dalam pemeriksaan dalam sidang MPW.

c. Kewenangan Majelis Pengawas Pusat (MPP)

Kewenangan MPP diatur dalam Pasal 77 dan 78 UUJN, antara lain:

a) menyelenggarakan sidang untuk memeriksa dan mengambil keputusan dalam tingkat banding terhadap penjatuhan sanksi dan penolakan cuti;

b. memanggil Notaris terlapor untuk dilakukan pemeriksaan sebagaimana dimaksud pada huruf a;

c. menjatuhkan sanksi pemberhentian sementara; dan

d. mengusulkan pemberian sanksi berupa pemberhentian dengan tidak hormat kepada Menteri.

a) 2)

Sebagaimana telah diuraikan diatas, telah tampak jelas bahwa ketentuan Pasal 67 ayat (1) UUJN telah mengamanatkan bahwa pembinaan dan pengawasan terhadap para notaris menjadi kewenangan Menkumham, yang bertujuan agar para notaris dalam menjalankan tugas jabatannya memenuhi semua persyaratan yang berkaitan dengan pelaksanaan tugas jabatan Notaris. Untuk melakukan pengawasan tersebut sebagian kewenangan Menkumham didelegasikan kepada Majelis Pengawas Notaris (MPN) yang dibentuk secara berjenjang mulai dari MPD, MPW hingga MPP.

Sanksi administratif dalam UUJN yang meliputi: a) peringatan tertulis; b) pemberhentian sementara dan c) pemberhentian dengan tidak hormat. Menkumham hanya mendelegasikan kewenangan mengenai pemberian sanksi administratif berupa peringatan tertulis kepada MPW. Sedangkan sanksi administratif lainnya yaitu pemberhentian sementara dan pemberhentian dengan tidak hormat tidak didelegasikan. Walaupun 
pemberian sanksi tetap menjadi kewenangan Menkumham, namun MPN secara berjenjang berkewajiban melakukan pengawasan terhadap notaris. Di mulai dari MPD yang berkewajiban melaporkan kepada MPW mengenai adanya notaris yang ditahan karena kasus pidana, berlanjut MPW lapor kepada MPP dan selanjutnya sampai kepada Menteri, sehingga notaris yang ditahan mendapat keputusan pemberhentian sementara dari Menteri selama masa penahanan dalam mengikuti proses hukum (vide Pasal 9 ayat (1) huruf e UUJN). Dengan demikian fungsi pembinaan dan pengawasan kepada notaris dapat berjalan dengan baik.

6. Kedudukan Notaris Yang Sedang Dalam Masa Pembebasan Bersyarat

a. Notaris Diberhentikan Sementara

Berdasarkan ketentuan Pasal 9 ayat (1) UUJN setelah dilakukannya perubahan dinyatakan 5 (lima) unsur yang dapat menyebabkan notaris diberhentikan sementara yaitu :

1. dalam proses pailit atau penundaan kewajiban pembayaran utang;

2. berada di bawah pengampuan;

3. melakukan perbuatan tercela;

4. melakukan pelanggaran terhadap kewajiban dan larangan jabatan serta kode etik Notaris; atau

5. sedang menjalani masa penahanan.

Unsur ke 5 (lima) di atas tidak diatur dalam UUJN sebelum dilakukannya perubahan dan baru diatur/dimasukkan pada waktu UUJN dilakukan perubahan dengan UndangUndang Nomor 2 Tahun 2014. Namun demikian pengaturan lebih lanjut mengenai tata cara pemberhentian sementara terhadap notaris yang sedang menjalani masa penahanan tidak mendapat pengaturan lebih lanjut dalam UUJN.

Dijadikannya seorang notaris sebagai tersangka hingga terdakwa hingga kadangkala harus dilakukan penahanan oleh polisi atau jaksa, sehingga menyebabkan notaris tersebut berhalangan untuk dapat menjalankan jabatannya. Oleh karenanya selama notaris menjalani masa penahanan tersebut dapat diberhentikan sementara untuk jangka waktu antara 3 (tiga) hingga (enam) bulan sesuai ketentuan Pasal 9 ayat (1) huruf e UUJN.

Penulis mendapati kerancuan/inkonsistensi mengenai siapa yang berhak memberhentikan sementara, yaitu antara pengaturan Pasal 9 dan Pasal 77 UUJN. Pada Pasal 9 ayat (3) disebutkan : "Pemberhentian sementara Notaris sebagaimana dimaksud pada ayat (2) dilakukan oleh Menteri atas usul Majelis Pengawas Pusat". Sedangkan pada Pasal 77 huruf c, dinyatakan bahwa : "Majelis Pengawas Pusat berwenang menjatuhkan sanksi pemberhentian sementara". Dari kedua ketentuan tersebut siapakah yang dapat menjatuhkan sanksi pemberhentian sementara. Apakah Menteri atau MPP, penulis berasumsi bahwa yang berwenang memberhentikan sementara adalah Menteri sedangkan MPP sebatas memberikan usulan kepada Menteri.

Disamping itu ketentuan Pasal 9 ayat (2) yang menyatakan : "Sebelum pemberhentian sementara sebagaimana dimaksud pada ayat (1) dilakukan, Notaris diberi kesempatan untuk membela diri dihadapan Majelis Pengawas secara berjenjang". Dari ketentuan tersebut masih layakkah dilakukan apabila notaris yang telah ditahan untuk mengikuti proses peradilan yang menjeratnya, diminta datang menghadiri sidang yang digelar oleh MPN secara berjenjang, mulai MPD, MPW hingga MPP, sekedar untuk melakukan pembelaan diri sehingga kemudian MPN dapat menjatuhkan putusannya untuk memberhentikan sementara notaris yang ditahan karena diduga melakukan tindak pidana.

Seharusnya Pasal 9 ayat (2) dapat diabaikan, sehingga dalam hal pemberhentian sementara kepada notaris yang sedang menjalani masa penahanan karena notaris telah ditahan oleh aparat hukum, sehingga MPD yang dibentuk di Kabupaten/Kota yang dianggap paling dekat dalam melakukan pengawasan terhadap notaris dan dianggap paling mengetahui atas kejadian di wilayahnya, secara berjenjang dapat memberikan laporan kepada MPW dan selanjutnya MPW memberikan laporan kepada MPP hingga mengusulkan kepada Menteri untuk dilakukannya pemberhentian sementara terhadap notaris yang terhalang karena sedang dalam masa penahanan (hukuman kurungan).

UUJN juga tidak memberikan pengaturan yang jelas mengenai jangka waktu pemberhentian sementara, pada tahap awal selama masih berstatus tersangka atau 
terdakwa. Apabila dalam persidangan diketahui bahwa ancaman pidana kurang dari 5 (lima) tahun, dan setelah vonis dijatuhkan serta telah inkracht, tentunya masa skorsing yang awalnya masih berstatus terdakwa, harusnya diperpanjang hingga berakhirnya masa hukuman. Dengan demikian selama skorsing, notaris yang bersangkutan tidak mempunyai kewenangan untuk menjalankan jabatannya sebagai notaris.

Pengaturan Pasal 9 ayat (1) huruf e UUJN tersebut menyebabkan notaris yang sedang menjalani masa penahanan harus diskorsing selama masa menjalani masa penahanan. Hal tersebut merupakan amanat undang-undang, dengan atau tanpa keputusan menteri mengenai pemberhentian sementara itu, baik karena lalainya MPN secara berjenjang mengusulkan kepada Menteri, atau karena lalainya Menteri itu sendiri dalam menjalankan undang-undang. Hal ini mengakibatkan hilangnya kewenangan notaris tersebut untuk menjalankan jabatannya selama masa hukuman harus dikenakan kepadanya.

b. Notaris Diberhentikan Dengan Tidak Hormat

Pendekatan kasus yang digunakan dalam penelitian ini, yaitu putusan Pengadilan Negeri Tual Nomor : 35 /Pid.Sus/2013/PN.TL, seorang notaris yang berkedudukan Kabupaten Maluku Tenggara telah didakwa menyimpan tanpa hak dan menyalahgunakan narkotika jenis sabu-sabu. Oleh jaksa penuntut umum, notaris tersebut dituntut dan diancam pidana menurut Pasal 112 ayat (1) Undang-Undang R.I. Nomor 35 Tahun 2009 tentang Narkotika. Ancaman hukuman pada Pasal tersebut adalah paling singkat 4 empat) tahun dan paling lama 12 (duabelas) tahun.

Atas tuntutan tersebut selanjutnya hakim menjatuhkan putusan/vonis pidana terhadap terdakwa tersebut oleh karena itu dengan pidana penjara selama 2 (dua) Tahun dan pidana denda sebesar Rp. 500.000.000,- (lima ratus juta) dengan ketentuan apabila pidana denda tersebut tidak dibayar maka diganti dengan pidana penjara selama 4 (empat) bulan.

Notaris yang terlibat dalam penyalahgunaan narkoba telah memenuhi unsur yang diatur dalam Pasal 12 huruf c berikut penjelasannya. Dengan demikian seharusnya MPP mengusulkan kepada Menteri agar notaris yang bersangkutan diberhentikan dengan tidak hormat.

Di samping itu, ancaman hukum yang dilanggar adalah paling lama 12 (duabelas) tahun melebihi unsur yang diatur dalam Pasal 13 UUJN. Dengan ancaman hukuman yang lebih dari 5 (lima) tahun, seharusnya Menteri dapat mengambil tindakan untuk memberhentikan dengan tidak hormat notaris tersebut karena telah memenuhi ketentuan Pasal 13 UUJN.

7. Notaris Menjalankan Jabatannya Kembali Walau Sedang Dalam Masa Pembebasan Bersyarat

Terkait kasus yang dikaji, nampak bahwa unsur MPN, yaitu MPD setempat tidak menjalankan fungsinya dengan baik, mulai dari tidak melaporkan dan mengusulkan skorsing selama masa penahanan kepada MPW dan seterusnya secara berjenjang, hingga tidak melaporkan serta mengusulkan agar notaris yang terjerat kasus pidana penyalahgunaan narkoba (vide Pasal 12 huruf c jo, penjelasannya), juga terhadap perbuatan pidana yang diancam dengan hukuman pidana lebih dari 5 (lima) tahun (vide Pasal 13 UUJN) diberhentikan dengan tidak hormat. Sehingga hal tersebut menyebabkan keputusan skorsing selama masa penahanan juga keputusan pemberhentian dengan tidak hormat tidak diterbitkan oleh Menkumham. Demikian juga terhadap protokol notaris yang seharusnya berdasarkan penetapan MPD dialihkan kepada notaris lain yang satu daerah (vide Pasal 63 UUJN).

Tidak diberikannya sanksi pemberhentian baik sementara ataupun pemberhentian dengan tidak hormat, atas vonis pidana yang dijatuhkan kepada notaris karena penyalahgunaan narkotika, menyebabkan notaris tersebut masih merasa berwenang untuk menjalankan jabatannya sebagai notaris yang disebabkan tidak adanya keputusan pemberhentian maupun karena protokol notaris masih dalam penguasaannya. Sehingga setelah dikeluarkan dari penjara karena mendapat hak pembebasan bersyarat, maka notaris tersebut kembali praktek dan membuka kantor notaris.

Sanksi terhadap notaris berupa pemberhentian sementara dari jabatannya dimaksudkan agar notaris tidak melaksanakan tugas jabatannya untuk sementara waktu sebelum sanksi berupa pemberhentian tidak hormat dijatuhkan pada notaris. Pemberian sanksi skorsing dapat berakhir dalam bentuk pemulihan kepada notaris untuk 
melaksanakan tugas jabatannya kembali atau ditindaklanjuti dengan sanksi pemberhentian dengan tidak hormat. Untuk memberikan kepastian maka skorsing tersebut harus ditentukan batas waktunya. Sanksi skorsing ini merupakan paksaan nyata, sedangkan dengan tidak hormat masuk kedalam ranah sanksi pencabutan keputusan.

Lalainya MPN ataupun Menteri dalam memberikan sanksi yang telah diatur dalam UUJN dapat menimbulkan ketidakpastian hukum. Hal tersebut menyebabkan notaris yang sedang menjalani hukuman pidana, seharusnya kewenangannya sebagai notaris dicabut sementara menurut UUJN. Namun karena MPN tidak menjalankan kewajibannya untuk mengusulkan kepada Menteri, perihal skorsing terhadap notaris yang sedang menjalani hukuman pidana kurungan, sehingga keputusan skorsing tidak dikeluarkan/diterbitkan.

Keputusan skorsing tersebut menjadi penting karena didalam keputusan tersebut tentunya memuat saat mulai dan berakhirnya skorsing. Tidak adanya keputusan skorsing menimbulkan ketidakpastian terutama mengenai saat berakhirnya pemberhentian sementara.

Kepastian hukum seharusnya untuk memberikan perlindungan hukum kepada masyarakat oleh pemerintah. Asas kepastian hukum adalah suatu jaminan bahwa suatu hukum harus dijalankan dengan cara yang tepat. Kepastian pada intinya merupakan tujuan utama dari hukum. Jika hukum tidak ada kepastian maka hukum akan kehilangan jati diri serta maknanya. Jika hukum tidak memiliki jati diri maka hukum tidak lagi digunakan sebagai pedoman perilaku setiap orang.

Ketidakpastian hukum mengenai tidak dikeluarkannya keputusan pemberhentian sementara tersebut, menyebabkan notaris yang sedang menjalani pembebasan bersyarat merasa masih memiliki kewenangan sebagai notaris sehingga begitu bebas bersyarat dari hukuman pidana kurungan, notaris tersebut kembali melayani masyarakat.

\subsection{Kedudukan Akta Yang Dibuat Oleh Notaris Yang Sedang Menjalani Masa Pembebasan Bersyarat}

Pasal 1868 KUH Perdata, merupakan sumber lahirnya akta otentik, mengingat bahwa pasal tersebut memberikan definisi tentang akta otentik, yang mengandung 3 unsur utama

a. Syarat Akta Notaris Sebagai Akta Otentik

Semua akta yang dibuat dihadapan Notaris dapat disebut sebagai akta otentik. Akta otentik diatur dalam Pasal 1868 KUH Perdata. Menurut Habib Adjie (2004, h.56), Pasal 15 ayat (1) UUJN menegaskan bahwa salah satu kewenangan Notaris, yaitu membuat akta secara umum, dengan batasan sepanjang :

1) Tidak dikecualikan kepada pejabat lain yang ditetapkan oleh undang-undang.

2) Menyangkut akta yang harus dibuat atau berwenang membuat akta otentik mengenai semua perbuatan, perjanjian, dan ketetapan yang diharuskan oleh aturan hukum atau dikehendaki oleh yang bersangkutan;

3) Mengenai subjek hukum (orang atau badan hukum) untuk kepentingan siapa akta itu dibuat atau dikehendaki oleh yang berkepentingan;

4) Berwenang mengenai tempat, dimana akta itu dibuat, hal ini sesuai dengan tempat kedudukan dan wilayah jabatan Notaris;

5) Mengenai waktu pembuatan akta, dalam hal ini Notaris harus menjamin kepastian waktu para penghadap yang tercantum dalam akta.

Akta yang dibuat dihadapan atau oleh Notaris berkedudukan sebagai akta otentik menurut bentuk dan tata cara yang ditetapkan dalam UUJN.

Notaris dalam menjalankan tugas jabatannya harus dalam keadaan aktif, artinya tidak dalam keadaan cuti atau diberhentikan sementara.

b. Nilai Pembuktian Akta Yang Dibuat Oleh Notaris Yang Sedang Menjalani Pembebasan Bersyarat

Pembatasan waktu (tempus) kewenangan notaris, yaitu notaris berwenang membuat akta otentik sejak diangkat hingga berhenti/ diberhentikan. Dengan pengecualian dalam kurun waktu itu terdapat hal-hal yang menjadikan notaris menjadi tidak berwenang walaupun belum berhenti/diberhentikan, yaitu dalam hal: 1) cuti; 2) diberhentikan sementara.

Apabila dikaitkan dengan kasus yang dikaji dalam penelitian ini, yaitu seorang notaris yang telah dijatuhi pidana karena penyalahgunaan narkoba, yang mana dalam masa pembebasan bersyarat, notaris tersebut kembali berpraktek dan membuka kantornya untuk melayani masyarakat maka kasus pidana penyalahgunaan narkoba 
yang menimpa notaris tersebut memenuhi unsur Pasal 13 UUJN, karena didakwa dengan ancaman hukuman paling lama 12 (dua belas) tahun, menyebabkan notaris diberhentikan dengan tidak hormat.

Pemberhentian dengan tidak hormat yang memenuhi ketentuan Pasal 13 tersebut merupakan amanat undang-undang (by law), dengan atau tanpa keputusan menteri mengenai pemberhentian dengan tidak hormat tersebut mengakibatkan notaris telah kehilangan kewenangannya sebagai notaris.

Notaris yang menjalani masa pembebasan bersyarat karena kasus narkoba yang kembali berpraktek dan melayani masyarakat, maka notaris tersebut telah menjalankan jabatan notaris tanpa wewenang (onbevoegdheid). Yang mengakibatkan akta yang dibuatnya tidak memenuhi unsur otentisitas akta yang diatur dalam Pasal 1868 KUHPerdata. Akibat hukum terhadap akta dibuat notaris tanpa kewenangan, maka akta tersebut tidak otentik.

\section{Kesimpulan}

a. Notaris sebagai pejabat umum sekaligus juga sebagai pejabat publik, sehingga harus selalu menjaga kehormatan dan martabatnya serta mempunyai kepribadian yang baik yang berlandaskan kode etik dan aturan-aturan hukum positif yang berlaku. Ketika seorang notaris melakukan perbuatan yang melanggar aturan hukum hingga dijatuhi hukuman pidana, maka UUJN akan menjatuhkan sanksi administratif yang dapat berupa peringatan tertulis, pemberhentian sementara hingga pemberhentian dengan tidak hormat. Dalam kaitan dengan kasus yang dikaji dalam penelitian ini, yaitu seorang notaris dijatuhi hukuman pidana karena penyalahgunaan narkoba dan kembali menjalankan jabatannya sebagai notaris ketika menjalani masa pembebasan bersyarat. Berprakteknya kembali notaris tersebut dikarenakan MPN yang dibentuk secara berjenjang oleh Menteri mulai MPD, MPW dan MPP, tidak menjalankan tugas, fungsi dan kewajibannya dengan baik. MPD yang berkedudukan di kota/kabupaten berkewajiban untuk mengetahui notaris di wilayahnya yang berhalangan melayani masyarakat, termasuk notaris yang menjalani masa penahanan. Lalainya MPD untuk melaporkan kepada MPW dan seterusnya mengakibatkan notaris yang menjalani masa penahanan dan kemudian divonis pidana oleh pengadilan tidak diberhentikan sementara oleh Menkumham. Terlebih lagi tindak pidana penyalahgunaan narkoba yang dilakukan notaris telah memenuhi unsur notaris tersebut untuk diberhentikan dengan tidak hormat atas usulan MPN menurut Pasal 12 UUJN. Adapun ancaman hukuman yang lebih dari 5 (tahun), juga memenuhi unsur bahwa notaris tersebut dapat diberhentikan dengan tidak hormat langsung oleh Menkumham. Dengan terpenuhinya unsur Pasal 12 dan 13 UUJN, maka secara hukum (by law) notaris yang dipidana karena penyalahgunaan narkoba telah kehilangan kewenangannya sebagai seorang notaris. Demi kepastian hukum, keputusan mengenai pemberhentian dengan tidak hormat tersebut wajib diterbitkan oleh Menkumham, agar pihak-pihak terkait dan notaris yang bersangkutan mengetahui kedudukan hukumnya bahwa notaris tersebut telah dicabut kewenangannya. Namun karena lalainya MPN memberikan usulan kepada Menkumham, maka keputusan pemberhentian tidak diterbitkan yang menimbulkan ketidakpastian hukum serta menyebabkan notaris yang bersangkutan masih merasa memiliki kewenangan sebagai notaris di samping karena protokol notaris masih dalam penguasaannya, sehingga dia kembali berpraktek ketika menjalani masa pembebasan bersyarat.

b. Tindakan notaris yang secara hukum (by law) telah kehilangan kewenangannya sebagai notaris yang kembali berpraktek dan melayani masyarakat dalam membuat alat bukti otentik ketika menjalani masa pembebasan bersyarat merupakan tindakan yang dilakukan tanpa wewenang. Syarat otentisitas akta notaris sebagaimana diatur dalam Pasal 1868 KUH Perdata yang terdiri dari 3 unsur utama secara kumulatif harus terpenuhi yaitu 1) di dalam bentuk yang ditentukan oleh undang-undang; 2) dibuat oleh dan di hadapan Pejabat Umum yang 
berwenang; 3) akta yang dibuat oleh atau di hadapan Pejabat Umum yang berwenang untuk itu dan di tempat dimana akta itu dibuat. Maka akta yang dibuat oleh/dihadapan pejabat umum yang tidak berwenang kehilangan otentisitasnya dan hanya menjadi akta dibawah tangan jika ditanda- tangani dengan sempurna. Tindakan notaris yang tanpa kewenangan tersebut dapat dikategorikan sebagai perbuatan melawan hukum. Bagi masyarakat atau pihakpihak didalam akta tersebut yang merasa dirugikan dapat menuntut tanggung jawab baik secara perdata maupun pidana.

\section{DAFTAR PUSTAKA}

Adjie, Habib. (2009). Sanksi Perdata dan Administrasi Terhadap Notaris Sebagai Pejabat Publik, Refika Aditama, Bandung. . (2013). Penafsiran Tematik Hukum Notaris Indonesia, Refika Aditama, Bandung. . (2014). Merajut Pemikiran dalam Dunia Notaris dan PPAT, Citra Aditya Bakti, Bandung.

Sjaifurrachman dan Habib Adjie. (2013). Aspek Pertanggungjawaban Notaris dalam Pembuatan Akta, Mandar Maju, Bandung.

Soegondo Notodisoejo, 1982, Hukum Notariat di Indonesia, Rajawali, Jakarta 